\title{
EDITORIAL
}

\section{E OS EVENTOS DA TERAPIA OCUPACIONAL}

No próximo ano realizaremos importantes eventos para os terapeutas ocupacionais brasileiros. De 2 a 6 de junho de 2003 ocorrerão, em Foz do Iguaçu, o VIII Congresso Brasileiro de Terapia Ocupacional e o V Congresso Latino Americano de Terapia Ocupacional. Assim, a excelente oportunidade de um grande número de profissionais brasileiros compartilhar experiências com colegas de outros países latino americanos está bem próxima. O tema principal dos encontros - organizados pela Associação Cultural dos Terapeutas Ocupacionais do Paraná - será "Saúde, Meio Ambiente e Qualidade de Vida".

Esses encontros, que têm sido para a categoria um dos mais importantes momentos para a exposição de estudos e para o aprofundamento de temas fundamentais para o desenvolvimento profissional, serão também pontuados por acontecimentos significativos. Estão previstos um encontro de instituições de ensino, um fórum dos centros acadêmicos e um fórum de entidades da categoria, reunindo associações, WFOT, CLATO e Crefitos. E ainda teremos eleições para as diretorias da ABRATO e da CLATO.

No encontro das instituições de ensino teremos oportunidade para conhecer e refletir sobre os recentes padrões mínimos da Federação Mundial de Terapia Ocupacional, cujo conteúdo certamente traz influências importantes no rumo da formação acadêmica dos profissionais. Aliás, a Comissão organizadora do evento tem investido esforços no sentido de contar com membros da WFOT e da CLATO nesses eventos, o que pode trazer ao fórum de entidades uma oportunidade ímpar de trocar experiências e promover ações que dizem respeito à organização da categoria.

O lançamento de livros promete ser também um ponto alto do evento. A possibilidade de reunir vários autores em um momento como esse mostra que a produção da Terapia Ocupacional no último período atingiu patamar relevante, considerando a realidade da profissão. Conhecer os autores e suas obras significa mais do que prestigiálos. Significa atualizar-se em relação às discussões mais atuais que se colocam no campo profissional.

Convém, ainda, lembrar, que além de conferências, mesas-redondas, debates e atividades culturais, os terapeutas ocupacionais poderão participar de cursos pré e póscongresso e oficinas.

Possivelmente, logo os terapeutas ocupacionais da América Latina contarão com informações mais detalhadas sobre a programação completa do evento, podendo se preparar para sua participação qualificada nos eventos.

\footnotetext{
Marta Carvalho de Almeida Docente do Departamento de Fisioterapia, Fonoaudiologia e Terapia Ocupacional e Editora da Revista de Terapia Ocupacional da USP
} 